\title{
The Demand for Human Rights in a Diverse Socio-Cultural World Society: Approaches and Tools
}

\author{
Vincent Dodoo \\ Department of History and Political Studies \\ Social Sciences Faculty, Kwame Nkrumah University of Science \&Technology, Kumasi, Ghana
}

Received: July 8, 2010

Accepted: August 7, 2010

doi:10.5539/jpl.v4n2p162

\begin{abstract}
The universality of human rights in a culturally diverse world and the approaches and tools for dealing with the problem is the subject of this paper. Since 1945, the United Nations accepted that human rights are rights applicable to all peoples on earth and, therefore, it became necessary to develop institutions to ensure that demands for such rights by peoples of the world can be met. A primary concern of this paper is to assess the institutions and machinery provided and to determine whether they are adequate and effective for meeting the demands.
\end{abstract}

This paper is divided into three parts: the origins of the human rights agenda, approaches for meeting human rights demands and the tools and instruments needed to enforce the demands.

Keywords: Cultural diversity, Human rights, Legal society, Universality, World society

\section{Introduction}

The global or world society (Dodoo, 2008) is not homogenous. The United Nations Organization, the umbrella organization which houses these heterogeneous groupings currently has about 192 member states (Hudson Institute, 2011) (Note 1) embracing all the different peoples and cultures on earth. The diversity is not just limited to the component member states but there is diversity within the individual member states. Danish society which used to be homogenous is no longer the case. That society is becoming very diverse culturally because different peoples from around the world have been allowed into the country for a variety of reasons, including acceptance of refugees who have been integrated into Danish society (Levinson, 1998:23-25). The member states of the UN include the highly industrialized/modernized countries of the North Atlantic tradition, the developing societies in Asia, Africa, Latin America and Oceania. Since these states together present such a high aggregation of cultural diversity, it is only normal to expect that attitudes to the same issue or even different issues are likely not to be the same in different parts of this conglomerate society. In trying to simplify the complexity of this cultural diversity, Mosler suggested that the various cultures and societies be grouped under legal and non-legal societies (Mosler, 1980). Western societies are then grouped under legal societies where the rule of law operates. However, the rest are placed under non-legal societies. It will be more appropriate to identify the legal society with the modern/industrial society as we find it in the countries of the North Atlantic tradition (WEOG). As it turns out, modernization/industrialization is more pervasive in the countries of the North Atlantic tradition than in the other remaining continents. Nevertheless, these sectors of the world society also have some amounts of modernization which are equally based on the rule of law.

In fact, within some modern societies remnants of traditional society, co-exist either in open competition for supremacy or, alternatively, the one which is the dominant sector leads the way and is hotly pursued by the other. This is the case in Ghana where modernization began slowly from the coast and moved upland. But sometimes, the traditional non-legal sector can penetrate the modern legal sector to cause extreme havoc. A case in point is the slowly developing time-bomb at the Fadama flatlands in Accra where the place has been besieged by a large population of head potters called Kayayei who hailed from the northern sector of the country. These are able-bodied young girls with no education and nothing else apart from their youth, energy and desire to work. They work as head potters during the day and sleep in the nearby sheds at night and are thus taken advantage of by the men and boys around so that they end up producing children who start life in such uncertain environment. When we speak of the rights of the child, the right to education, the right to housing and good health, will the implementation be so easy at Fadama as compared to Teshie-Nungua Estates or Mamprobi? This question takes me back to the issue of human rights, what they are and where they come from.

\section{Origins and Current Status of The Human Rights Agenda}

The Human Rights program in the world today is essentially claims on governments by groups made up of individuals for the provision of conditions conducive for a good life (Lindholm, 1998:15). Such claims have become necessary 
because of the pervasiveness of people's inhumanity to others. The abhorrent and degrading treatment of man by man over the years has taken several different forms such as: the exploitation of people (labour), enslavement (both individuals and whole populations), torture of varieties of descriptions, forced labour, denial of freedom of expression, of free movement and association, of the right to work and earn a decent living, detentions and confinements and wholesale persecution of peoples, among others.

Whereas such degrading behaviours have been with people over the ages, in the recent past, certain activities of states and within states have led to the intensification of the problem of threats to the freedoms of humans that cannot go on unattended to. The Fadama case may be explained by the issue of urbanisation as well as the explanations which go into the causes of the rural-urban migration in the developing country. This problem is, however, neither peculiar to Ghana nor to the developing country. The emergence of urban centres in the dying stages of feudalism in Europe produced similar concerns (Hobsbawm, 1968).

In addressing the issue of the intensification of the problem of more threats to the freedoms of people in recent times, Tore Lindholm, the coordinator of the research program in human rights and plurality at the Norwegian Centre for Human Rights, enumerates ten scenarios for consideration. These are:

1. Modern remains of feudal oppression and feudal bondage.

2. The murderous ravages of religious, civil and internal wars.

3. Violations of peoples' freedoms, integrity, property or safety by a despotic state.

4. Violent ethno-national conflicts

5. Modern slavery

6. Moral arbitrariness wrought and made conspicuous by unrestrained market forces.

7. Colonial conquests, domination and exploitation

8. Patterns of discrimination on racial, ethnic or gender grounds.

\section{Genocide}

\section{Mass killings of civilians in wars (Lindholm, 1998:9).}

These sources of threats to the freedoms of people have collectively challenged the responsible world statesmen to assess the problem and respond with the expectation of containing the anomalies for the better future for the world society. In fact, several studies have been conducted with the view to determining the origins of the human rights agenda today. Some of such studies tried to trace the roots to biblical times such as the work of Eva Marie Lassen, a research fellow at the Danish Institute for Human Rights. Micheline Ishay, on the other hand, makes a bold effort to recount the dramatic struggle for human rights across the ages from the Mesopotamian Codes of Hammurabi to the present era of globalization (Ishay, 2008).

Despite the views of such studies, there is one researcher from Oslo, Tore Lindholm, who has argued that the modern human rights agenda properly belongs to the Second World War and its aftermath. He has maintained that the word "human rights" did not even exist in the English language before 1940. He admits that the terms "natural rights" and the "rights of man" which predate "human rights" have some relevance in the discussion of the subject matter but insists that the two terms do not cover the same terrain that Human Rights of today have come to occupy. Tore Lindholm argues that the current Human Rights program began effectively from the period of the Second World War and was “...the outcome of protracted discussions conducted in the organs of the United Nations about the normative grounds of universal human rights norms, a justification rationale for human rights can be spelled out as a piece of practical reasoning” (Lindholm, 1998: 4).

He has pointed out that the stringent universality of present day human rights and the dual accountability structure for safeguarding these rights belong uniquely to the new international order that arose out of World War II under the auspices of the United Nations Charter (Lindholm, 1998:7). As a point of fact, an earlier attempt to include in the League of Nations Covenant a statement on racial equality sponsored by Japan was rejected by the four Western Nations of Britain, Australia, France and the United States (Lindholm, 1998:7). According to Lindholm, the rejection of the principle of human dignity by the four states was because it would have undermined the legitimacy of their colonial empires: "Human Rights irrevocably undermines the international legitimacy of colonialism and racial discrimination and that watershed was brought about by World War II” (Lindholm, 1998: 7).

In the course of that war, as a result of provocations from the German camp, the allied leaders inaugurated a project of codifying universal human rights in international law and included into the war platform of the Allied Powers, a pledge to make, human rights legally binding everywhere in the world (4 Freedoms Speech of Roosevelt in 1941) 
(Lindholm, 1998:10). That German provocation was further heightened when after Hiroshima, fear of the use of the nuclear weapon against civilian targets were added (Lindholm, 1998:10). Around 1945, therefore, universal human rights were widely seen and strongly supported as a politically feasible remedy against future recurrences of similar horrors, that is, preventing war and protecting equal rights being thought of as two sides of one coin (Lindholm, 1998: $10)$.

These then were some of the subtle explanations of the background to the design and subsequent adoption of the UDHR (1948) which is the first of the three documents which collectively give the world society its International Bill of Rights, the other two being the CESCR (1966) and the CCPR (1966) (United Nations, 1993:1). Out of these three documents, 39 freedoms or rights have been identified as available to all peoples of the world which they can claim. These include: equality of rights without discrimination; Life; Liberty and security of person; Protection against slavery; Protection against torture and cruel and inhuman treatment and punishment, among others (List provided as Appendix).

Norbeto Bobbio speaks of the Age of Rights which today witnesses widespread and intense debate on human rights interpreted as a prophetic sign of humanity's moral progress since it is so widespread as to involve all peoples of the world and so intense as to be on the agenda of most authoritative judicial bodies (Bobbio, 1996:35). Kirsten Hastrup also suggests that there is a legal language which includes a universal language of human rights which requires to be kept general and open-ended to be able to accommodate all the varieties of experiences which should be a precondition for the flourishing culture of human rights (Hastrup, 1998a:2). In her paper on Anthropology's Comparative Consciousness, she raises the issues of ethnographies of violence and sufferings and of the vultures of disaster " a reference to a complex human experiences of undignified behaviour, of violence and downright evil that not only disrupts individual and communal life-courses but also erupts as silences into social discourses” (Hastrup, 1998b:17). This scenario painted above requires to be confronted by the cultures of progress and it is the latter which would eventually prevail. According to Hastrup " this is the optimistic baseline for a renewed acclaim of human rights, not simply as a way of talking but as an expression of human solidarity beyond the diverse vocabularies and the will to create universal ethics” (Hastrup, 1998b:18). This is the shared secular religion of Multilateralism of Jose Alvarez (Blum, 2008:1).

\section{Approaches for Making the Demands}

There are two basic approaches for making human rights demands. Accordingly, the rights are divided into two, that is, those rights which are special to the individual and are called individual rights and those which are applicable to a group and are thus called collective rights. The CCPR (Convention on Civil and Political Rights) takes care of the individual rights while the CESCR (Convention on Economic, Social and Cultural Rights) takes care of the group rights. This is the explanation for the existence of two covenants instead of one.

We can use Kwame Nkrumah's method for equipping Africa to be able to function in an integrated world society to illustrate how the two approaches work. He, that is, Kwame Nkrumah, a renowned Pan-Africanist and first President of the Republic of Ghana, operated at three levels of the systemic (Africa/World), the sub-systemic (Ghana) and then the individual. The individual needed to the equipped to function freely without hindrances to be able to be effective. And he could only do this if he was in a conducive environment (Afari-Gyan, 1976). The first set of rights he needed was thus the individual rights whereas the second were the collective rights at the sub-systemic and the systemic levels. In the sub-systemic and the systemic levels, colonialism had to be dismantled and new structures for development had to be put in place to create the conducive atmosphere for the individual to flourish and realise himself.

Indeed, the issue of development as a human right became a matter of heated debate between the East and the West as well as between the South and the North at one point at the UN General Assembly leading eventually to the adoption of the Declaration of the Right to Development by the General Assembly of $4^{\text {th }}$ December 1986 (Lindholm, 1998:13). On this issue of development and human rights, one question which required an answer was whether development could ever be seen as a right and if human rights promotion could be seen as development. The answer is clear and it throws more light on the issue of collective rights. The argument is that development can be seen as a right when development activities become entitlements, that is, when claims can be legitimately made for development by people on authorities in control of resources and power. The CESCR thus deals with conditions of work, trade unions, social security, protection of the family, standards of living and health, education and cultural life. It provides that rights in these categories are to be realised progressively and without discrimination. The CCPR, on the other hand, deals with issues like freedom of movement, equality before the law, presumption of innocence, freedom of conscience and religion, freedom of opinion and depression, peaceful assembly, freedom of association, participation in public affairs and elections and minority rights. It prohibits arbitrary deprivation of life, torture, slavery, forced labour, arbitrary arrest, and detention, arbitrary interference with privacy, war propaganda, etcetera. The covenant provides for a 
Human Rights Committee to consider measures taken to implement its provisions and a conciliation procedure to deal with allegations that parties have failed to live up to those provisions.

\section{The Tools and Instruments}

The tools for making the demands are institutional facilities and legal instruments. The institutional facilities exist at the international, regional/continental and national/local levels. The UN is the first body with an interest in human rights observation by member states and it has a machinery for enforcement, the details of which are spelt out in UN Fact Sheet Number 1 of 1988 and briefly summarised below:

1. The UN Charter makes reference to human rights and fundamental freedoms in a number of clauses. In the Preamble, the people of the UN express their determination "to reaffirm faith in fundamental human rights, in the dignity and worth of the human person, in the equal rights of men and women and of nations large and small". In Article 68, the Economic and Social Council is empowered to set up commissions "in economic and social fields and for the promotion of human rights".

2. The General Assembly is the main representative body of the UN and article 13 of the Charter specifies as one of its functions to initiate studies and make recommendations for the purpose of 'promoting international cooperation in the economic, social, cultural, educational and health fields and assisting in the realisation of human rights and fundamental freedoms for all without distinction as to race, sex, language or religion”.

3. Since the adoption of the UDHR (Universal Declaration of Human Rights) in 1948, the General Assembly has adopted numerous declarations/conventions concentrating on human rights. They deal, among other things, with genocide, racial discrimination, apartheid, refugees, stateless persons, rights of women, slavery, marriage, children, youth, aliens, asylum-seekers, disabled and mentally retarded persons, issue of torture, development and social progress.

4. Article 62 of the Charter tasks the Economic and Social Council to "make recommendations for the purpose of promoting respect for and observance of human rights and fundamental freedom for all. Article 68 empowers it to set up commissions for the protection of human rights. Such commissions which have been set up include the Commission on Human Rights, (1946), the Sub-Commission on Prevention of Discrimination and Protection of Minorities (1947) and the Commission on the Status of Women (1946)

5. Other bodies established in accordance with UN Human Rights instruments include the Committee on the Elimination of Racial Discrimination (1970), Human Rights Committee (1977), Committee on Economic, Social and Cultural Rights (1985), Committee on the Elimination of Discrimination against women (1982), Committee against Torture (1987) and the Group of Three Established under the International Convention on the Suppression and Punishment of the Crime of Apartheid.

6. Indeed, the Secretariat of the UN itself, has a Centre for Human-Rights and there is an Under Secretary-General responsible for Human Rights.

7. Other UN bodies which support directly its human rights program include the ILO, UNESCO, FAO and the WHO. There is also a UN High Commissioner for Refugees.

8. Article 71 of the Charter authorises ECOSOC to make suitable arrangements for consultation with NGO's which are concerned with matters within its competence. The Council accordingly, has arrangements with several hundred international and national organizations which are contained in resolution 1296 (1968) of ECOSOC.

In studying or dealing with certain human rights problems, UN organs frequently call upon NGOs or national organizations in consultative statuses to supply information, particularly on existing de facto situations. And the NGOs have been very generous in their cooperation thereby enhancing the role and facilitating the task of the UN in the field of human rights. A recent innovation within the UN set up to further enhance its work in the field of human rights is the creation of the Office of the High Commissioner for Human Rights to coordinate all activities related to human rights. There is also the Special Rapporteur on Torture and the UN Fund for the Victims of Torture.

The last two facilities deal with the problem of torture and one international organisation which has an interest in that area is the Copenhagen-based International Rehabilitation Centre for Victims of Torture (IRCT). Other private international human rights watchdogs and centres are Amnesty International, Greenpeace and the International Red Cross Society. Their activities generally complement UN efforts and they do cooperate with it wherever necessary.

At the regional or continental level, we can mention the CPT (Committee for the Prevention of Torture) for Europe and the CAPSDH (African Commission of Health and Human Rights Promoters) for Africa, as examples. At the national/local level, we can cite the Office of the Ombudsman for Denmark as well as the Commission for Human Rights and Administrative Justice (CHRAJ) for Ghana. In Ghana, there are also several privately run NGOs 
preoccupied with the problem of human rights observation. These include Dr. Edmund Delle's CAPSDH which is actually a rehabilitation centre for torture victims (Rabito Clinic), Baffour Anning's African Human Rights Heritage, Akuffo-Addo and Baidoo-Ansa's Ghana Committee on Human and Peoples Rights and Kobina Andrew's Human Rights Forum. Others are International Association of Women Lawyers-Ghana, the Ghana Journalists Association, the International PEN (Ghana Chapter) and the Civil Liberties Centre.

The legal instruments available for enforcing human rights in our culturally diverse world society include the UN's International Bill of Rights out of which a minimum of 39 rights and freedoms become available for claim by all peoples who belong to the UN Community. This Bill has three components.

a) UDHR (1948) which is a soft law

b) CESCR (1966) which is a hard law, and

c) CCPR (1966) with its optional protocols, which is also a hard law (Note 2).

Otherwise, the legal instruments can be grouped into three, that is, international (UN), regional/continental and national. Under the international, we can further distinguish between general instruments, specific instruments, instruments for group protection and those against discrimination. For the International (UN), the CCPR and the CESCR come under General; the Convention against Torture and other Cruel, Inhuman or Degrading Treatment or Punishment comes under Specific; the Convention Relating to the Status of Refugees as well as the International Convention on the Protection of the Rights of all Migrant Workers and Members of their Families come under Group Protection while CEDAW remains under Against Discrimination. In the case of Regional/Continental, The African Charter on Human and People's Rights is an example. The relevant section in the 1992 constitution of Ghana is an example for the National.

An important question to pose at this stage is whether these instruments as they exist today are adequate and also whether they have been effective in dealing with human rights demands in this culturally diverse world society. A preliminary answer to the first question is that, the instruments are adequate. They exist at the national, continental and international levels and the provisions are comprehensive. If we take the case of Ghana, the 1992 Constitution makes ample provisions to guarantee human rights protection for all the citizens. At the continental level, Ghana is a signatory of the African Charter on Human and People's Rights, which is a comprehensive document providing human rights protection for all African peoples. Ghanaians are equally provided cover under the International Bill of Rights. Since April, 2009 at San Francisco attempts are being made to incorporate the international bill of rights into the UN Charter itself. We can also say that these provisions are adequate because their existence have necessitated the creation of institutional facilities to further enhance implementation. For instance, the Committee on the Elimination of Discrimination against Women was established in 1982 in accordance with article 17 of CEDAW (United Nations, 1996:11). Also, the Committee against Torture was established in 1987 in accordance with article 17 of the Convention against Torture and other Cruel, Inhuman or Degrading Treatment or Punishment (IRCT, 1996:21). The same applies to the Human Rights Committee which materialised because of article 28 of the CCPR (United Nations, 1993:30).

It would be such an unfortunate situation if a person who felt aggrieved because of a wrong should get to an institution for redress only to find out that there was no remedy for that particular complaint. Fortunately, the instruments are comprehensive enough and, therefore, this is not a problem for the human rights redress machinery. The problem with the human rights machinery is largely one of implementation of the existing instruments and, sometimes, this is so because of the problem of cultural diversity. Other times, some countries simply refuse international scrutiny by refusing to ratify those conventions which would make this possible. Ghana was one of the guilty ones in this area until quite recently when the Ghanaian Parliament decided to adopt resolutions to sign and ratify 6 of the UN conventions including the two hard law conventions of the International Bill of Rights and the Convention against Torture. This was $28^{\text {th }}$ July 2000. And this was due to the prompting of the Civil Liberties Centre, when observing the UN day set aside for supporting victims of torture on $26^{\text {th }}$ June 1999 , challenged the Ghana government to come out openly and explain why it was unwilling to ratify the Convention on Torture (Dodoo, 1999a). Otherwise, Ghana's national constitution contains ample provisions to guarantee human rights for all the citizens and the country remains a signatory to the African Charter. Despite these realities torture, for instance, existed in the country in a big way and there were forced disappearances as well as unexplained disappearances of people.

\section{Conclusion}

Danish society used to be homogenous. This is no longer the case as that society is becoming very diverse culturally because several groupings from around the world have been allowed into the country for a variety of reasons including acceptance of refugees who have been integrated into the Danish society. In December, 1998 during the $50^{\text {th }}$ anniversary celebration of the UDHR in Copenhagen, representatives of the muslim community made a passionate appeal to the Danish authorities to be permitted to build a mosque in the city for prayers. Such an appeal cannot be said 
to be unreasonable since the largely dominant Lutheran Danish society permitted the muslims to come into their midst, to begin with. That was a human rights demand. On the other hand, a muslim family has the choice not to send its children to a catholic school, but if this happens, that family cannot expect the school to change its curriculum to accommodate the muslim pupils. If the muslim community is a sizeable one (Note 3), it can ask for a muslim school.

The problems which confronted the former dictator of Chile, General Augusto Pinochet when he visited Britain for medical treatment and the difficulties the Mauritanian military officer had to undergo at Montpelier in France all suggest that there are now few safe havens in the world for torturers, for instance (Note 4). And this current situation in the world has been made possible by the existence of the UN Convention Against Torture and other Cruel, Inhuman or Degrading Treatment or Punishment. This convention requires signatories to the convention (state parties) (Note 5) to take into custody torturers who visit their country and arrange for their trial. Anybody from any country in the world can seek such a redress from any state party and expect to have redress. The various other listed instruments and legal machinery at the national, regional and international levels make several rights available for all the culturally diverse peoples on earth. The approaches, instruments and tools are adequate and effective in providing redress when the demands are made at the national, regional and international levels, thereby, enhancing international cooperation among all peoples on earth.

\section{References}

Afari-Gyan, K. (1976). The Political Ideas of Kwame Nkrumah. New York: African Heritage Studies.

Blum, G. (2008). Bilateralism, Multilateralism and the Architecture of International Law. Harvard International Law Journal. 49(2): 323-379. http://www.harvardilj.org/wp-content/uploads/2010/09/HILJ_49-2_Blum.pdf (January8, 2009)

Bobbio, N. (1996). The Age of Rights, Cambridge: Polity Press.

Dodoo, V. (2008). A Historian of World Society: A Study of the Historian Eric Hobsbawm and a Critique of his Age of Capital, Journal of Science and Technology, 28:2, pp. 102-116.

Dodoo, V. (1999b). Commentary on the Arrest of Captain Ely Ould Dah in France and the Expulsion of 40 French Soldiers from Mauritania, The Ghanaian Independent, $10^{\text {th }}$ August, pp.8,11.

Dodoo, V. (1999a). Statement on the UN International Day in Support of Victims of Torture, (Press Conference, Accra: Kata International Hotel), $26^{\text {th }}$ June.

Hammond, J.L and B. (1951). The Rise of Modern Industry, London: Methuen.

Hastrup, K. (1998a). Declaring a Culture of Rights: Legal Language and the Legacy of Modernism, in J. Cowan, M.B. Dembour, R. Wilson eds. Culture and Rights: Anthropological Investigations, Cambridge: CUP.

Hastrup, K. (1998b). Anthropology's Comparative Consciousness: The Case of Human Rights, Paper presented at the Comparison in Anthropology International Workshop, University of Vienna, September.

Hobsbawm, E.J. (1968). Industry and Empire: Economic History of Britain since 1750. London: Wiedenfeld and Nicolson.

Hudson Institute. (2011). Political Alliances Within the UN, Eye on the UN ( A project of the Hudson Institute of New York and Touro College Institute for Human Rights), NY. [Online] Available: http://www.eyeontheun.org/view.asp?p=55\&1=11(April 6, 2011)

IRCT. (1996). International Declarations and Conventions, Copenhagen: International Rehabilitation Centre for Victims of Torture.

Ishay, M.R. (2008). The History of Human Rights: From Ancient Times to Globalization Era, Berkeley: University of California Press.

Jean-Bernard. (1997). International Instruments Relating to Human Rights, Human Rights Law Journal. Special Edition.

Lassen E.M. (1998). Origins of the Human Rights Agenda. Working Paper: DCHR/DCMR, Copenhagen. Illuminating Human Rights: Biblical and Roman Perspectives.

Levinson, D. (1998). Ethnic Groups Worldwide: A Ready Reference Handbook, Phoenix: Oryx Press. (Pages 23-25)

Lindholm, T. (1998). Islam and Human Rights, Oslo: University of Oslo Research Project.

McDougal, M., Lasswell, H. \& Chem,L-C. (1980). Human Rights and World Public Order: The Basic Policies of an International Law of Human Dignity. New Haven and London: Yale Press. 
Mosler, H. (1980). The International Society as a Legal Community. Alphen aan den Rijn, The Netherlands: Sijthoff \& Noordhoff International Publishers B.V.

Roosevelt, F.D. (1941). Four Freedoms Speech. $77^{\text {th }}$ US Congress, $6^{\text {th }}$ January.

Republic of Ghana, (1992). Constitution of the Republic of Ghana. Accra: Ghana Publishing Corporation. pp. 12-34.

United Nations. (1988). Human Rights Machinery (Fact Sheet No 1). Geneva: United Nations.

United Nations. (1993). The International Bill of Human Rights, New York: United Nations.

United Nations. (1995). National Human Rights Institutions: A Handbook on the Establishment and Strengthening of National Human Rights Institutions, Geneva: Centre for Human Rights.

United Nations. (1996). Convention on the Elimination of Discrimination Against Women, Geneva: UN Department of Public Information.

\section{Notes}

Note 1 . The UN is unofficially divided into five regional groupings. The Asian Group (54 members), the African Group (53 members), the Latin American and Caribbean Group (GRULAC) with 33 members, Western European and Others Group (WEOG) with 28 members and Eastern European Group (CEIT or countries with economies in transition) with 23 members. The US is not a member of any of the groups but votes with WEOG. Israel is the only UN member state which is not a full member of any of the groups (Eye on the UN). http://www.eyeontheun.org/view.asp?p=11(April 6, 2011).

Note 2. All municipal laws are hard laws in that they are binding and enforceable. Some international conventions are equally binding on the signatories and are also called hard laws like the CCPR and the CESCR. International Law, generally, provides a framework or platform for hard laws to be developed and the UDHR is a good example of this and is accordingly called a soft law.

Note 3. The muslim community is about $50 \%$ of the non-Danish community in Denmark which is $3 \%$ of the country's population (Levinson, 1998:23-25).

Note 4. Captain Ely Ould Dah was arrested in 1999 while on a training program at Montpelier in France upon a complaint to French authorities by two Mauritanians he had previously tortured in Mauritania. In 1998, Pinochet went to the UK for medical treatment but was arrested under an international arrest warrant issued by Spanish judge, Balthasar Garzon, for human rights atrocities committed in Chile from 1973-1990. http://news.bbc.co.uk/2/hi/3085482.stm (April 7, 2010).

Note 5. Signatories to the Convention Against Torture and other Cruel, Inhuman or Degrading Treatment or Punishment are called state parties.

\section{APPENDIX: 39 FREEDOMS AND RIGHTS AVAILABLE TO ALL PEOPLES}

1. Equality of rights without discrimination

2. Life

3. Liberty and security of person

4. Protection against slavery

5. Protection against torture and cruel and inhuman punishment.

6. Recognition as a person before the law

7. Equal protection of the law

8. Access to legal remedies for rights violations

9. Protection against arbitrary arrest and detention

10. Hearing before an independent and impartial judiciary

11. Presumption of innocence

12. Protection against ex post facto laws

13. Protection of privacy, family, and home

14. Freedom of movement and residence

15. Freedom to seek asylum from persecution

16. Citizenship 
17. Marry and found a family

18. Own property

19. Freedom of thought, conscience and religion

20. Freedom of opinion, expression and the press

21. Freedom of assembly and association

22. Democratic participation as a vehicle of popular self-government.

23. Social security

24. Work under decent conditions

25. Free trade unions

26. Rest and leisure

27. Adequate levels of food, clothing, housing

28. Adequate levels of health care and social services

29. Special protection for children

30. Education

31. Participation in cultural life

32. A social and international order that facilitates the realisation of human rights.

33. Self-determination

34. Humane treatment when detained or imprisoned

35. Protection against debtors prison

36. Protection against arbitrary expulsion of aliens

37. Protection of minority culture, language or religion

38. Protection against advocacy of racial or religious hatred

39. Special protection of women. (Source: Lindholm, 1998) 